\title{
Device Selection
}

\author{
Nancy L. Moureau and Evan Alexandrou
}

\section{Abstract}

Selection of the right vascular access device requires assessment using an algorithmic process, as represented in quadrants 1 and 2 of the VHP model, to provide the patient with a tailored device suited to patient-specific clinical conditions. The process of device selection includes a rational assessment of the patient's needs, vein anatomy and health and medical history as well as consideration of the characteristics of the prescribed therapy, in conjunction with proper knowledge of the proposed treatment. However, the first consideration

N. L. Moureau $(\bowtie)$

PICC Excellence, Inc., Hartwell, GA, USA

Menzies Health Institute, Alliance for Vascular Access Teaching and Research (AVATAR) Group, Griffith University, Brisbane, QLD, Australia e-mail: nancy@piccexcellence.com

\section{E. Alexandrou}

School of Nursing and Midwifery, Western Sydney University, Penrith, NSW, Australia

Central Venous Access and Parenteral Nutrition Service-Liverpool Hospital,

Liverpool, NSW, Australia

Menzies Health Research Institute-Alliance for Vascular Access Teaching and Research (AVATAR) Group, Griffith University, Brisbane, QLD, Australia

Faculty of Medicine, South West Sydney Clinical School, University of New South Wales Australia, Sydney, NSW, Australia

e-mail: e.alexandrou@westernsydney.edu.au must be whether the patient's therapy truly justifies administration via an indwelling VAD. This first step is often overlooked in acute healthcare settings, where more than $90 \%$ of therapies involve some form of IV administration. With developments in modern drugs, there may well be an oral administration alternative that is equally acceptable and, as such, is less risky to the patient. Perhaps the right VAD is no VAD at all!

\section{Keywords}

Selection $\cdot$ Catheter $\cdot$ Central venous

Peripheral intravenous $\cdot$ Risk $\cdot$ Complications Infection - Vein anatomy · Vein size Infusion therapy

\subsection{Types of Vascular Access Devices}

Vascular access devices are characterized as either peripheral or central, dependent on whether the distal end of the device terminates in the peripheral veins of the body or the larger central veins. Vascular access devices (Fig. 3.1) include:

- Peripheral cannula

- Extended dwell/ultrasound-guided cannula

- Midline catheters

- Central venous access devices 


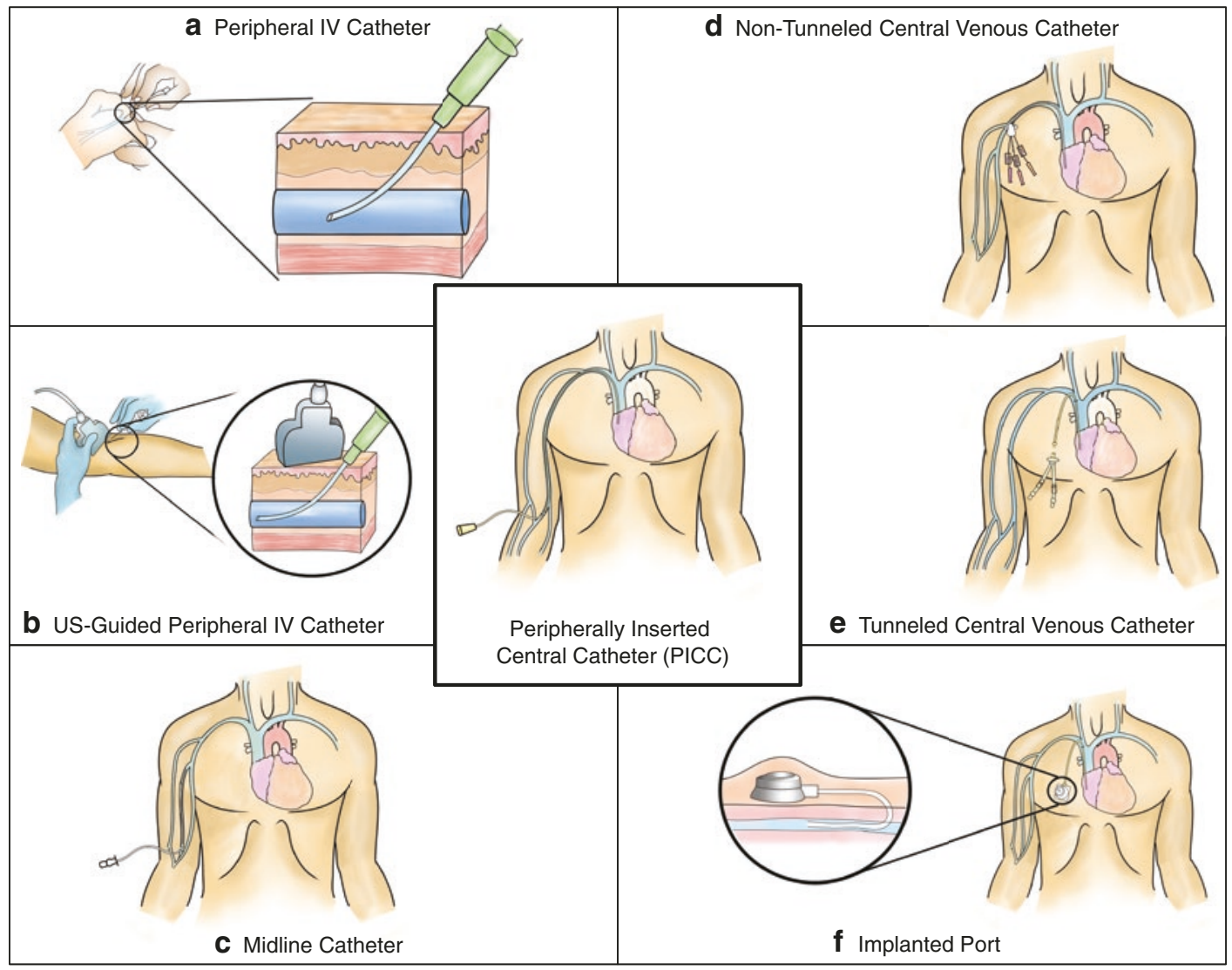

Fig. 3.1 Types of venous access devices (Chopra et al. 2015). IV intravenous, $U S$ ultrasonography. (a) Peripheral IV catheter. These devices are typically $3-6 \mathrm{~cm}$, enter and terminate in the peripheral veins (cross-section), and are often placed in the upper extremity in veins of the hand. (b) US-guided peripheral IV catheter. Ultrasonography may be used to facilitate placement of peripheral intravenous catheters in arm veins that are difficult to palpate or visualize. "Long" peripheral IV catheters (typically $\geq 8 \mathrm{~cm}$ ) that are specifically designed to reach deeper veins are also available for insertion under US guidance. (c) Midline catheter. These devices are $7.5-25 \mathrm{~cm}$ in length and are typically inserted in veins above the antecubital fossa. The catheter tip resides in the basilic or cephalic vein, terminating just short of the subclavian vein. These devices cannot accommodate irritant or vesicant infusions. (d) Nontunneled central venous catheter. Also referred to as "acute" or "short-term" central venous catheters, these are often inserted for durations of $7-14$ days. They are typically $15-25 \mathrm{~cm}$ and are placed via direct puncture and cannulation of the internal jugular, subclavian, or femoral veins. (e) Tunneled central venous catheter. These differ from nontunneled catheters in that the insertion site on the skin and site of ultimate venipunc- ture are physically separated, often by several centimeters, reducing the risk for bacterial entry into the bloodstream and facilitating optimal location of the catheter for care of the exit site. Tunneled devices may be cuffed or noncuffed; the former devices have a polyethylene or silicone flange that anchors the catheter within the subcutaneous tissue and limits entry of bacteria along the extraluminal surface of the device. (f) Implanted port. Ports are implanted in the subcutaneous tissue of the chest and feature a reservoir for injection or aspiration (inset) and a catheter that communicates from the reservoir to a deep vein of the chest, thus providing central venous access. Ports are cosmetically more desirable than other types of central venous catheter and can remain in place for months or years. (g) Peripherally inserted central catheter. These long vascular access devices $(>45 \mathrm{~cm})$ are inserted into peripheral veins of the upper arm in adults and advanced so that the tip of the catheter resides in the lower portion of the superior vena cava or upper portion of the right atrium. They are similar to central venous catheters in that they provide access to the central circulation, but they do so without the insertion risks associated with direct puncture of deep veins in the neck, chest, or groin 


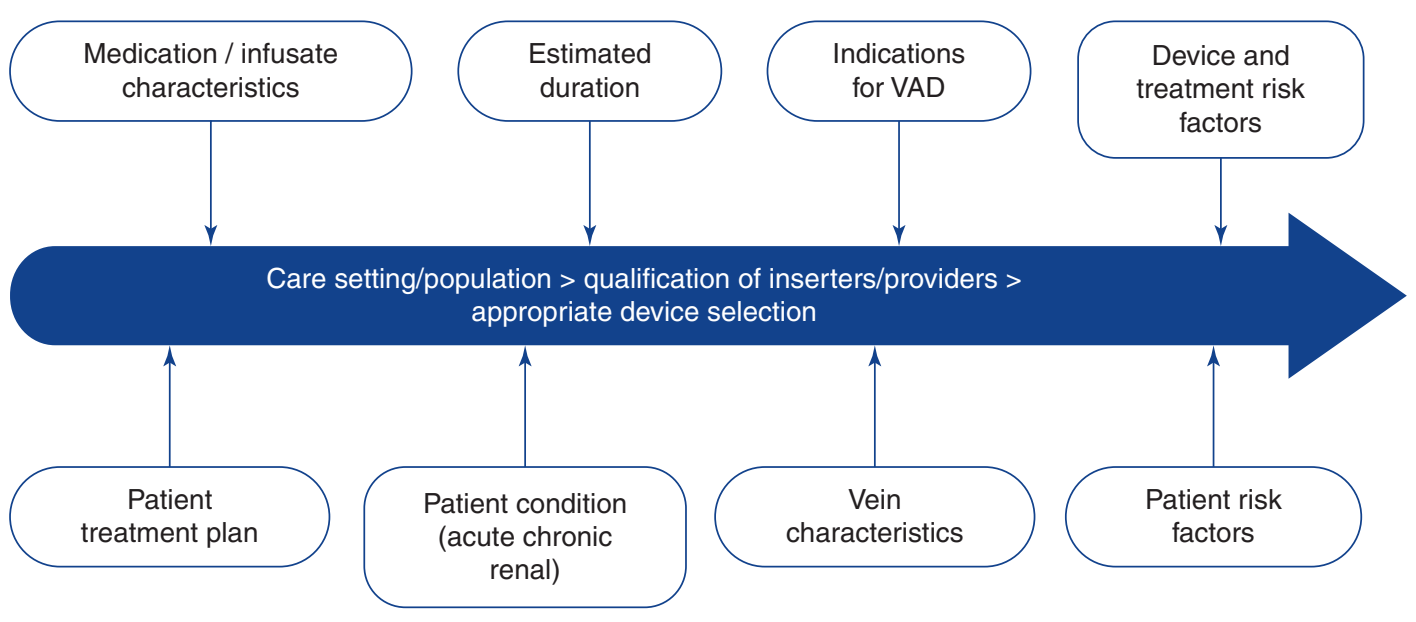

Fig. 3.2 Selection criteria for vascular access device (used with permission N. Moureau, PICC Excellence)

Although not considered a traditional form of VAD, administration of emergency drugs via the intraosseous route is gaining prominence in emergency care protocols where the insertion of a formal VAD cannot be successfully achieved in a timely manner. Whilst not central to discussion of VHP, the intraosseous (IO) route should still be borne in mind as an alternative with emergencies or when intravenous access is not attainable.

The selection and insertion of the most appropriate device for IV therapy are based on a number of key factors (Fig. 3.2):

\subsection{Short Peripheral Intravenous Cannula (PIVC)}

A short peripheral intravenous cannula (PIVC) is a catheter less than $7.5 \mathrm{~cm}$ in length, most commonly inserted in the veins of the hand, forearm or region of the antecubital fossa. PIVCs are used for the infusion of non-irritating, non-vesicant treatments and are a consideration for placement when qualifying treatments are expected to last for less than 5 days. Solutions with high osmolarity are considered irritants or vesicants based on the response of the tissue to the solution. Irritating or vesicant medications and those with an osmolarity greater than $900 \mathrm{mOsm}$ require larger veins for maximum haemodilution to avoid complications and should not be routinely given through a PIVC (Gorski et al. 2016). Irritating medications administered through a PIV should be avoided except in urgent situations, and the device should be replaced as soon as warranted due to patient condition. Complications associated with the use of irritating medications or solutions through catheters with peripheral terminal tip placement include phlebitis, thrombosis, occlusion and other complications arising from damage or inflammation of the vein wall. Dwell time is based on clinically indicated removal (Gorski et al. 2016; Rickard et al. 2012a). Peripheral cannulae are removed when a complication occurs or when therapy is completed.

\subsection{Extended Dwell Peripheral (EDP) Cannula}

An extended dwell cannula is a peripheral cannula measuring less than $8 \mathrm{~cm}$ but designed with a longer cannula $(3-7.5 \mathrm{~cm})$ to facilitate ultrasound-guided placement, deeper vein access and longer dwell (Castro and Allison 2012; Gorski et al. 2016). Placement varies but is preferred in the veins of the forearm or upper arm with a catheter long enough to ensure at least two-thirds of the catheter length will reside in the vein after insertion. Infusate considerations and dwell time are the same as with peripheral cannula (INS 2016). EDP may, at times, be considered a midline catheter depending on length and placement location. 


\subsection{Midline Catheter}

A midline catheter is a longer peripheral cannula most commonly inserted into the upper arm via the basilic, cephalic or brachial veins, with the internal terminal tip located below the level of the axilla, distal to the shoulder (Gorski et al. 2016; Adams et al. 2016; Moureau and Chopra 2016). Midline catheter length ranges from $8 \mathrm{~cm}$ up to $20 \mathrm{~cm}$. Midline should not extend to the axillary vein or enter the chest. As with short peripheral IV catheters, midline catheters are not used if the osmolarity of prescribed solution is greater than $900 \mathrm{mOsm}$ or the solution is considered irritating or vesicant. Haemodilution, which aids in protecting the vein from damage caused by irritating solutions, occurs at a lower rate in the smaller peripheral veins; therefore, irritating medications are not recommended for non-central placement. Characteristics of certain medications and their level of irritation can be mitigated with dilution resulting in lower concentrations of the irritant. Insertion of a midline catheter is performed in a sterile manner. Midline catheters are available in different lengths, materials (i.e. silicone or polyurethane) and differing insertion methods (i.e. over the needle peelaway, accelerated Seldinger, Seldinger). A midline catheter is considered appropriate when therapy extends beyond 2 days up to approximately 14 days; however, dwell time of a midline catheter does not often exceed 4 weeks and follows clinically indicated removal (Chopra et al. 2015). Optimal dwell time for a midline catheter is unknown and based on complications or clinical need for removal with completion of treatment (O'Grady et al. 2011a, b).

\subsection{Central Venous Access Device}

A central venous access device (CVAD) is a catheter or implanted port where the tip terminates in the vena cava either superior or inferior depending on upper or lower extremity placement.

The types of CVADs are:

- Peripherally inserted central catheters (PICCs)

- Non-tunnelled devices
- Tunnelled devices

- Implantable ports

CVADs facilitate the delivery of medications and solutions into larger central vessels providing greater haemodilution, reducing the risk of chemical phlebitis and ensuring rapid distribution and clinical effect. The advantages of CVAD are that they can be used to infuse any medication. The disadvantages are the potentially life-threatening insertion-related complications ( $\mathrm{RCN}$ 2005; Scales 2008) of air embolism, haemorrhage, pneumothorax and post-insertion thrombosis or infection.

\subsubsection{Peripherally Inserted Central Catheter (PICC)}

A PICC is a central venous cannula inserted through peripheral veins of the extremities or neck with the tip residing in the distal portion of the superior vena cava (SVC) or inferior vena cava (IVC) (Gorski et al. 2016). Any PICC positioned with the terminal tip outside the SVC/IVC is considered malpositioned and is not considered a PICC as the termination is no longer central. PICCs are indicated for patients receiving IV therapy for periods greater than 5 days or when irritating medications or solutions are required (Chopra et al. 2015). As a centrally positioned catheter, PICCs can be used to administer any type of fluid or medication. Terminal catheter tip is confirmed via electrocardiogram (ECG) positioning method, x-ray or fluoroscopic guidance verifying SVC IVC placement prior to use. Complications associated with PICCs include most commonly infection, thrombosis and occlusion. Dwell time is based on clinically indicated removal when a central line is no longer necessary or when a complication develops; optimal dwell time is unknown (O'Grady et al. 2011a, b).

\subsubsection{Non-tunnelled Acute Care Catheter}

Non-tunnelled acute care catheters are inserted via percutaneous access into the internal jugular, subclavian, axillary or femoral veins and are typi- 
cally used for patients in acute care requiring critical access. As with all central catheters, the terminal tip is positioned in the SVC/ IVC. Available in standard polyurethane, silicone and antimicrobial materials, and configured as single, dual, triple and quad lumens, these catheters are commonly used in critical care areas. Dwell time is often limited to 7-14 days since this is one of the highest-risk catheters and risk of infection increases with the number of days the catheter is in situ (Maki et al. 2006). Dialysis catheters are intentionally excluded from this discussion.

\subsubsection{Tunnelled Long-Term Catheter}

A tunnelled long-term catheter (neck, chest or groin) is a device that exits the vein in one location and is tunnelled under the skin to a separate exit site, where it emerges from underneath the skin. These catheters are held in place by a Dacron cuff adherent to the catheter, just underneath the skin at the exit site. The exit sites of tunnelled CVADs are most commonly located on the chest to facilitate catheter care. Passing the catheter under the skin in a tunnel may minimize bacterial movement along the insertion tract of the catheter into the vein. The tunnel also provides stability by anchoring the catheter with a Dacron cuff around the catheter positioned just under the skin in the tunnel and adherent within fibrous and subcutaneous tissue. Owing to their more invasive and permanent nature, tunnelled catheters are generally used for patients who require nutritional support or long-term venous access. Removal of tunnelled catheter requires dissection of the adherent cuff within the tunnel.

\subsubsection{Subcutaneous Implanted Intravenous Port}

Implanted ports considered a long-term CVAD are placed by surgical technique; they are positioned by creating a pocket in the subcutaneous tissue of the chest, arm, abdomen or leg, sliding the port into the pocket and connecting a centrally placed catheter to the port. The catheter, previously advanced into the SVC/IVC, is attached to the port by way of a clip or metal cuff that holds the catheter on the port entrance. Ports have a minimal maintenance when not in use; monthly flushing is all that is recommended to maintain patency (Camp-Sorrell 2011). Implanted ports have a lower risk of infection compared to other external tunnelled and non-tunnelled central lines (Maki et al. 2006). The insertion of a port allows a patient to have minimal body image change owing to the implanted nature of the device with minimal visibly. Physical activity is not impaired with ports; swimming is allowed when the port is not accessed. The disadvantages of ports include some anxiety and discomfort associated when port is accessed with a Huber needle. Training is recommended for the nurse unfamiliar with the steps of port access. The first access should be supervised by another professional familiar with the procedure, along with a review of the hospital policy and instructions for use of the device.

\subsection{Other VAD Selection Factors}

\subsubsection{Quality of Infusate}

The characteristics of the infusate can dictate device selection. Solution or medication concentration, level of irritation, vasoactivity and chemical makeup will determine whether the medication is compatible with peripheral devices or requires a CVAD (Alexander and Hankins 2009; Gorski et al. 2016; Stranz 2002).

\subsubsection{Length of Therapy}

The duration of intravenous therapy impacts appropriate device selection (Chopra et al. 2015). The use of a peripheral intravenous catheter (PIVCs) for peripherally compatible medications in the short term is appropriate; however extended duration of therapy with PIVCs would not be suitable even if the medication is peripherally compatible. PIVC usage would come under scrutiny if the duration of use is intended 
to exceed 14 days due to the ongoing need for device replacement related to device failure (Wallis et al. 2014).

Those factors determining the length of time a patient will remain in an acute care bed include speed of diagnosis, initiation of treatment, consistent administration of treatment and response to treatment plan. Whilst evaluation of the diagnosis and treatment plan is ongoing, factors such as failed vascular access and delays in administration of medications are variables that impact the evaluation of adequate patient response to the treatment.

Kokotis, in her publication of 2005, described the impact of reduced length of stay as an area of cost reduction dependent on reliable drug infusion via a reliable vascular access device from the onset of therapy resulting in outcome improvement and the potential reduction on length of stay for the facility (Kokotis 2005). In a study conducted at Brigham and Women's Hospital/ Harvard Medical School in Boston, Robinson et al. found the institution of a peripherally inserted central catheter (PICC) team using bedside ultrasound for placement reduced their cost of placement and reduced delays in patient discharge resulting in a savings to the hospital estimated at \$950,000 (Robinson et al. 2005). In another study conducted by the University of Michigan, savings with length of stay reductions were minimal, at $3 \%$ or less, since the highest cost is at the beginning of the stay (40\%) and average cost per day at the end of hospitalization was $\$ 304$ (Taheri et al. 2000).

Based on the savings with Robinson's group, the reductions from early placement of bedside PICCs by a specialized team resulted in earlier discharges, adding up to significant savings to the facility. Initiation of a process to select those patients most at risk as length of stay outliers, those spending more than 6 days in acute care, has the greatest potential of improving the outcomes for the patient and resulting in decreased length of stay.

Vessel Health and Preservation utilizes evidence to support the best choice of VAD based on expected duration of treatment and infusate characteristics of peripheral compatibility or irritating nature of medication (Babu et al. 2016; Chopra et al. 2015). The knowledge of device selection algorithms can help prevent common problems with peripheral devices such as phlebitis and infiltration but also more serious complications that include bloodstream infection and thrombosis (Moureau and Chopra 2016).

\subsubsection{Patient Assessment for Device Selection}

Reducing risk and unnecessary harm in the hospital environment begins with assessment of the patient's condition, history, risk assessment and relative vessel health (Figs. 3.3 and 3.4). Matching the patient's current state of health with the need for intravenous access prevents unnecessary IV restarts, reduces medication delays, is economically efficient and provides for optimal outcomes.

There are specific patient conditions that may increase the risk of complications or require special treatment or knowledge when placing vascular access devices. Knowing these risk triggers in advance and planning for specialized treatment for placement of devices when these risks are present provide for safer vascular access and better outcomes for the patient. The recommendations presented here are consistent with published guidance from organizations such as the Joint Commission, the National Patient Safety Goals (NPSG), the Centers for Disease Control and Prevention, the Institute for Healthcare Improvement, the Infusion Nurses Society, the American Society of Diagnostic and Interventional Nephrology, the Oncology Nursing Society and the Society for Healthcare Epidemiology of America (SHEA) strategies (Camp-Sorrell and Matey 2017; Gorski et al. 2016; Hoggard et al. 2008; IHI 2012; Joint Commission 2017; O' Grady et al. 2011a, b).

\section{When selecting a vascular access device, it is important to:}

- Minimize the size of the catheter and select the smallest and shortest catheter possible to achieve infusion requirements without complications

- Select the fewest number of lumens; fewer lumens equal less risk for infection 
Patient MRN:

Age: Admission Date: Discharge Date:

LOS:

Diagnosis List: 1.

2. 3.

Infusions: 1. 2.

3.

4. 5.

- Daily assessment of device need documented for each day? Yes / No

- Documentation of device choice based on assessment of patient need and risk factors? Yes / No

- Documentation of vein health prior to device insertion? Yes / No

- Catheter / Vein Ratio Documentation? Yes / No

- Assessment for Right Device with in 24 hours? Yes / No

Vascular Access Risk Factor Selection: Check all that apply

\begin{tabular}{|l|l|}
\hline Limited Arm Use: CVA, Mastectomy, & $\square$ Age > or = 65 years \\
Trauma & $\square$ History of multiple IV attempts for one \\
$\square$ Renal Failure & successful IV \\
$\square$ Steroid Use & $\square$ Metastatic Disease \\
$\square$ Diabetes & $\square$ Antibiotic Infusion \\
$\square$ HTN & $\square$ Chemotherapy Infusion \\
$\square$ IV Drug Use & $\square$ Continuous IV Drip \\
$\square$ Failed IV Access in < 24 hours & $\square$ Parenteral Nutrition \\
$\square$ Previous Central Line Use & $\square$ Blood Product Transfusion \\
& \\
\hline
\end{tabular}

\section{Device Data:}

\begin{tabular}{|l|l|l|l|l|l|l|}
\hline Device & Attempts & $\begin{array}{l}\text { Date of } \\
\text { Insertion }\end{array}$ & $\begin{array}{l}\text { Date of } \\
\text { Removal }\end{array}$ & Dwell Time & $\begin{array}{l}\text { Complication } \\
\text { Type }\end{array}$ & $\begin{array}{l}\text { Reason for } \\
\text { Removal }\end{array}$ \\
\hline & & & & & & \\
\hline
\end{tabular}

Fig. 3.3 Patient assessment and VHP audit data collection tool (used with permission N. Moureau, PICC Excellence)

- Select the largest vessel possible to maximize dilution of medications with a terminal tip location appropriate to that medication and risk

- Consider the risk associated with insertion of a particular device and patient condition given the patient's vascular access needs to determine risk/benefit ratio

- Select location and/or extremity with healthiest veins

- Select the device that is least invasive but most appropriate for treatment and duration

- Evaluate for renal dysfunction (creatinine greater than 2.0 or GFR $<59 \mathrm{~mL} / \mathrm{min} / 1.73 \mathrm{~m}^{2}$ ) and avoid the use of the cephalic veins (preserve for future fistula formation)
- Seek to accomplish required device placement within 24-48 h of admission

- Use multidisciplinary approach when performing patient evaluation

\subsubsection{Evaluation of Patient Risk Factors}

Once the best vascular access device has been indicated based on the diagnosis, required therapies and duration of therapy, the patient is assessed to determine if there are any additional risk factors that contraindicate that device or require special placement considerations for the person/ department placing the device (Figs. 3.5 and 3.6). 


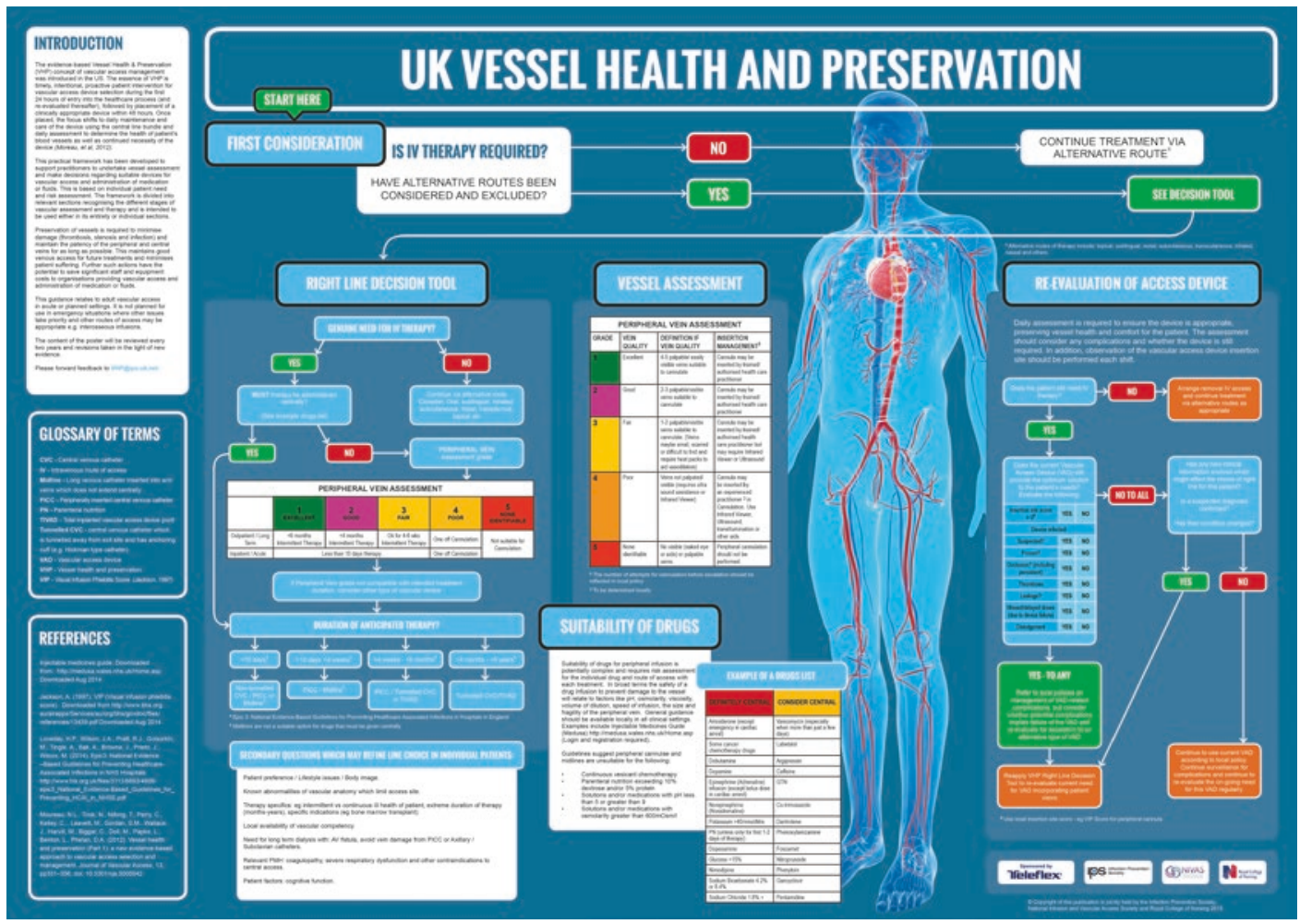

Fig. 3.4 UK vessel health and preservation (used with permission of Carole Hallam and the Infection Prevention Society)

\subsubsection{Stage 1 Assessment: Skin Condition (Fig. 3.5)}

The most substantial barrier to infection available to any patient is his own skin. When the skin is healthy and intact and free of disease, breaks or other trauma, it provides an occlusive covering preventing bacteria from entering the body. Any break in the skin anywhere on the body provides a portal of entry for bacteria on the skin to enter the body and begin to colonize with the potential to cause infection.

When venous access is required, a puncture is made through the skin and then into the vein. The puncture site now provides a portal of entry for bacteria to enter the body and move directly into the bloodstream along the path of the catheter or directly from within the catheter. To limit the number of bacteria entering the bloodstream, antiseptics are used on the skin to reduce and kill the bacteria around the intended site prior to the venipuncture. Additionally, an occlusive dressing is used to act as a temporary protective skin layer in conjunction with an extra chlorhexidineimpregnated sponge if desired. For these procedures to provide effective protection, they must be performed correctly. The antiseptics must be allowed to dry, and the skin integrity must be intact. In other words, the skin must be healthy enough to withstand the frictional scrub of an antiseptic, and it must be strong enough to allow a dressing to adhere to it in an occlusive manner.

When assessing a patient for risk factors prior to placement of a venous access device, the following factors should be considered:

- Are there skin conditions such as lacerations, abrasions, rashes or psoriasis that prevent an intended site from being accessed?

- Is the skin around the intended insertion site in a condition to safely manage punctures, abrasive cleaning and an occlusive dressing (free from haematomas, skin tears, burns or other forms of skin breakdown)? 


\section{Vessel Health and Preservation Protocol \\ Right Patient Tool - Risk Factors}

Directions: Check all that apply.

These risk factors may require a referral or a consult for a vascular access specialist to place indicated device.

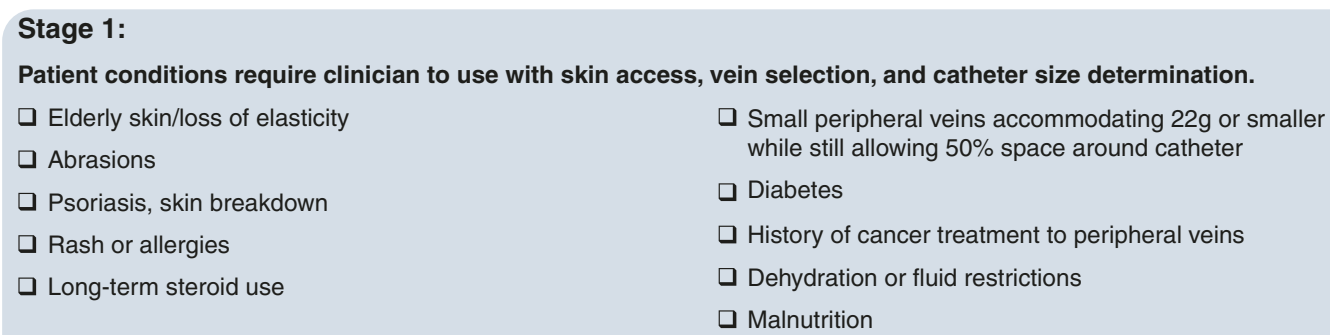

These conditions are known to commonly require multiple restarts. Any patient requiring 2 or more restarts within 24 hours should automatically be referred to Stage 2 and a vascular access consultation.

\section{Stage 2: \\ Patient conditions require extra care and referral to Vascular Access Specialist for consultation. \\ $\square$ High volume fluid needs: blood or blood by-products, intravenous medications, antibiotics, pain meds, TPN/PPN, chemotherapy, inotropes, other types (list not inclusive) \\ $\square$ Limited peripheral access due to single side mastectomy, chest or neck surgery, amputation of arms, infection, cellulitis, fistula, trauma or Injury, bums, hematomas, obesity $>250$ lbs \\ - Circulatory status: Stroke, hemiparesis, thrombosis to upper extremity, sign of illegal drug use, elevated INR, fistulas or shunts, severe dehydration or edema/fluid overload, DVT \\ Previous complications: presence of CVC, frequent IV restarts, history of poor access, hourly blood \& draws, required central line access in past \\ Critical factors: Acuity, life sustaining infusions, inotropes, unstable cardiac status, confirmed MI, arrhythmia, respiratory compromise \\ - Pediatric patient: less than 8 years old, child with high activity level (Pediatric specialist) \\ Creatinine levels $>2.0$. Requiring nephrologist OK prior to PICC line placement. \\ Do not attempt to place device yourself. Refer to Vascular Access Specialist for consultation and placement.}

\section{Stage 3:}

Patient conditions require clinician to refer patient to Interventional Radiology or Surgeon for placement of any vascular access device.

- History of radiology access placement

U Upper extremity DVT

Renal failure requiring Dialysis catheter

Do not attempt to place device yourself. Refer to Interventional Radiology or Surgeon for placement.

Fig. 3.5 Right patient tool—risk factors (used with permission of Teleflex)

Some conditions may contraindicate the use of certain venous access devices. The following conditions which affect skin integrity should cause the clinician to pause, consider complications that may be triggered by the condition and determine if another device or site should be chosen based on the patient's individual skin presentation:

- Elderly skin/loss of elasticity

- Geriatric patients

- Lacerations

- Abrasions
- Haematomas

- Psoriasis

- Rash or allergies

- Long-term steroid use (causes thinning of the skin)

- Diabetes

- History of cancer treatment to peripheral veins

- Dehydration or fluid restrictions

- Malnutrition

Remember, the skin is the patient's most substantial barrier to protection from infection. Inserting a vascular access device breaks that 


\section{Vessel Health and Preservation Protocol Right Line Contraindication Tool}

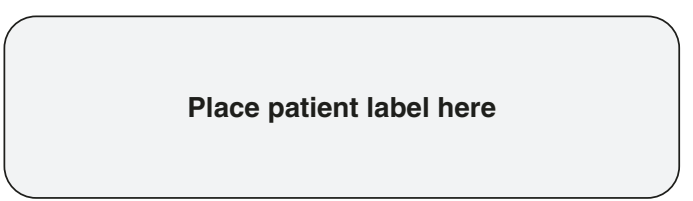

Use this tool to determine any risk factors or contraindications that may prevent use of the "right line" as determined by PAGE 1 of the Right Line Tool.

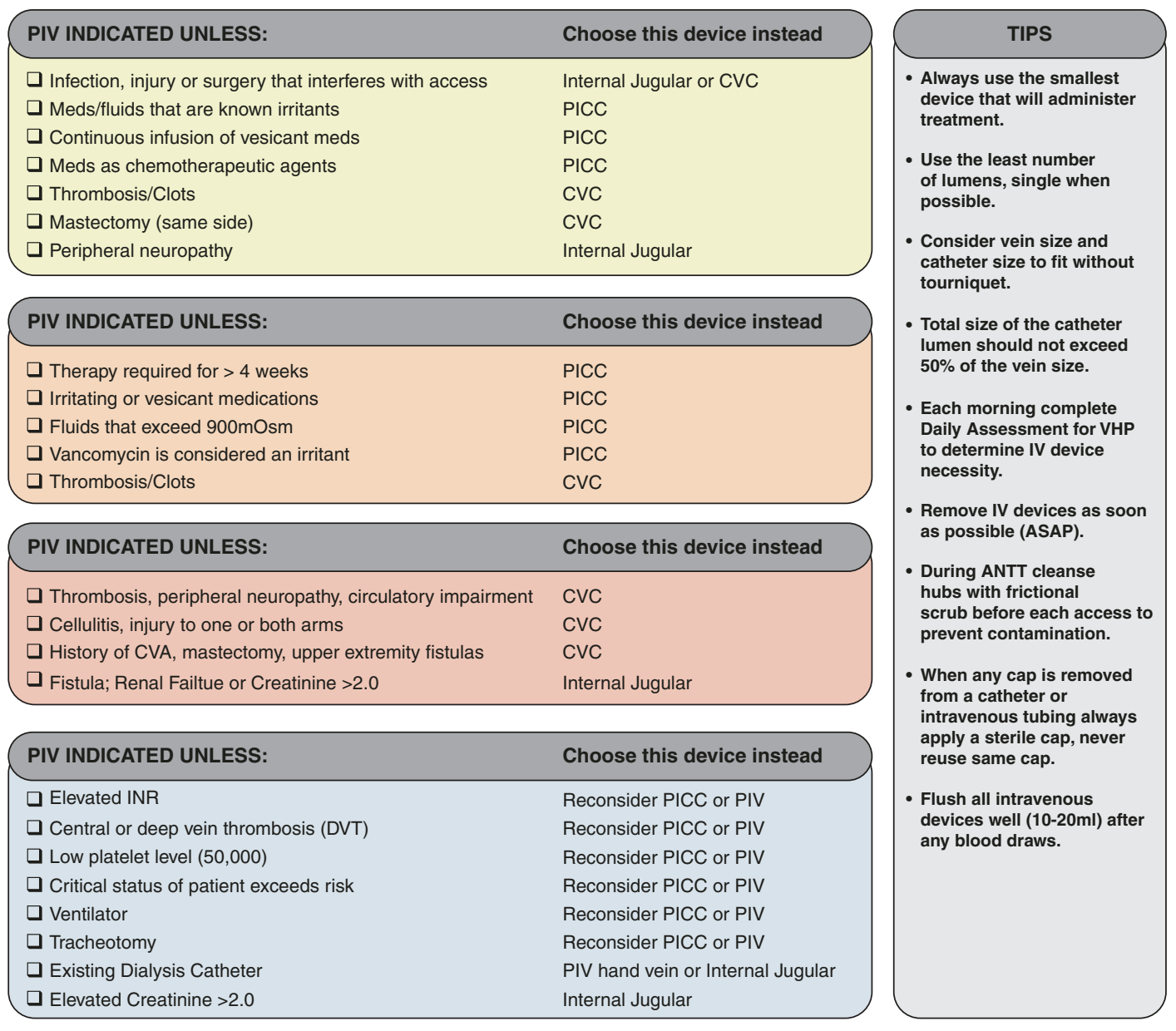

$\square$ No Contraindications present $\square$ Device Contraindicated $\square$ Device Contraindicated

Person determining contraindication of device:

Fig. 3.6 Right line contraindication tool (used with permission of Teleflex)

barrier. Prior to puncturing the skin, pause and consider if this is the best place on the patient's body to break that barrier, and if so, determine how to adequately provide protection to limit the number of bacteria entering the body at that site.

In addition to evaluating skin integrity, consider risks associated with bacterial concentration on various parts of the body. Bacteria are present in differing colony counts throughout the body based on temperature, hair follicles and sebaceous glands. Lower counts of bacteria are present on cooler structures such as the arms and legs. As you move from the extremities toward the main trunk of the body, temperatures increase along with bacterial counts. Because the main body is warmer and usually covered by clothing, 
bacterial counts are approximately twice that of the extremities. Places such as the groin, the axilla and even the neck have high bacterial counts. When selecting the best insertion site with the lowest risk based on bacterial counts, start from the extremities, and move inward. The groin carries the highest count of bacteria followed by the neck, then the chest and, last, the extremities, with the lowest count.

As with all evaluations of risk, there are many factors to consider when selecting the best site for vascular access selection; integrity of the skin, bacterial counts, risk with insertion and underlying structures all play a part in determining a safe access site for the patient.

\subsubsection{Stage 2 Assessment: Vein Conditions and Special Requirements}

Once the integrity of the skin has been evaluated, the patient's health history and vasculature must be assessed. Although the skin may appear to be relatively healthy and able to withstand abrasive cleaning and the application of an occlusive dressing, the underlying anatomy may tell a different story.

Certain patient conditions may contraindicate the use of an otherwise indicated device or may require special placement of the device by a vascular access specialist (Fig. 3.5). Any time a patient has a limited extremity, has small peripheral veins or veins that the clinician cannot visualize, expects to receive treatment for more than 5 days or has any other limiting factors, the patient should be referred to a vascular access specialist. The specialist can assess the veins using ultrasound to determine the optimal access site and device for that individual patient. Some additional factors requiring special attention include:

\subsubsection{Limited Peripheral Access}

A patient with limited peripheral access due to chronic treatments, a mastectomy, breast cancer, chest or neck surgery, amputation of the arms, infection or cellulitis anywhere along the arms, a fistula, trauma or injury needs special assessment for a device that will last the full length of therapy. Patients with multiple IV attempts, high INRs, low platelets or haematomas may require assessment and placement of device by a specialist. Obese patients are particularly challenging and require a specific plan for maintaining access.

\subsubsection{High-Volume Fluid Needs}

Those patients with high-volume fluid needs require a larger catheter to support the volume of the fluid. Placement of a larger catheter requires an ultrasound assessment of the patient's venous anatomy to determine the optimal access site based on the size of the veins. When administering blood/blood by-products and certain medications (antibiotics, pain meds, TPN/PP, chemotherapy, inotropes), the risk to the patient is higher if the device malfunctions thus necessitating larger vein access.

\subsubsection{Circulatory Status}

Patients with signs of poor circulation, peripheral neuropathy, a history of stroke, hemiparesis, fistulas or shunts that restrict flow, recurrent thrombosis or other conditions that impact circulation require vascular access performed in such a way as to avoid the affected area(s). These patients may require ultrasound assessment to determine the safest location and vascular access device.

\subsubsection{Previous Complications}

Those patients who have previously experienced complications with vascular access devices are more likely to have additional complications. Simply the presence of a CVC increases the risk of complications. Patients who require frequent IV restarts, have poor access and need hourly blood draws or other multiple line accesses may require assessment by a specialist for the best device. 


\subsubsection{Critical Factors}

Intensive care patients require many forms of access to accommodate a variety of high-risk medications and solutions. Any patient needing more than two access points for intravenous medications should have a plan for the best access device rather than relying on the access device of the moment. Many types of life-sustaining infusions or inotropes for patients with unstable cardiac status, confirmed MI, arrhythmias or respiratory compromise frequently need a device for longer than 5 days and thus meet the recommendation for consideration of a central venous catheter. Evaluation of a patient's condition and critical status lends itself to early planning to select the right line for the patient to allow treatment access over the full length of therapy.

\subsubsection{Other Conditions}

Certain conditions place a patient at greater risk for complications with access devices. Patients with chronic conditions such as haematologic and oncologic disease where risk of coagulopathy is great, history of illegal drug use or multiple devices can all lead to challenges with vascular access choices. PICCs may or may not be appropriate for those patients with peripheral injury or overuse. Careful consideration for the right line, in conjunction with the therapy and length of treatment, is paramount with this patient population.

\subsubsection{Paediatric Patients}

Patients under the age of 8 are particularly challenging for vascular access. Avoiding the trauma of multiple attempts and developing a clear plan for the best device for the patient are most important for paediatric patients. Clinicians with paediatric experience may perform access easily but may or may not be trained with central venous catheter access. Vascular access specialists can perform assessments and aid in the selection of the right line for the patient's treatment.

\subsubsection{Stage 3 Assessment: Interventional Radiology Placements}

Some patients have predisposing conditions that do not allow for peripheral placement of a device or have a history of difficulty with peripheral or central placement. These patients are candidates for referral to interventional radiology or to a surgeon for placement of a dialysis catheter, tunnelled device or implanted port. The focus for renal patients is on internal jugular placement with avoidance of the subclavian or use of arm veins that may inhibit later fistula placement as with PICCs (Hoggard et al. 2008). Some specific conditions include:

- Renal failure patient requiring dialysis catheter (creatinine $>2.0$ or GFR $<60 \mathrm{~mL} /$ $\min / 1.73 \mathrm{~m}^{2}$ )

- Patient with upper extremity deep vein thrombosis

- Patients with a history of radiology access placement

- Contraindication of both extremities

- Bilateral mastectomy/lymph node dissection

- Patient with multiple IV drugs/lumen access

- Unsuccessful PICC access attempt(s)

Because these patients may have limitations and do not have veins or extremities available or their extremities do not provide a safe and healthy option for access, the patients require a centrally inserted vascular access device which must be placed by a surgeon or by interventional radiology.

The focus of the Vessel Health and Preservation Protocol is to provide timely, intentional, proactive patient intervention for vascular access device selection during the first hours of entry into an acute care facility with device placement of the most appropriate catheter within the first days of treatment. Performing risk assessment prior to placement of an indicated device allows the clinician to check for risk factors, critical conditions, acuity, contraindications and infusion needs confirming this patient is indeed the right patient 
Table 3.1 Vein identification scale for inserter selection (modified) (used with permission of the Infection Prevention Society (Hallam et al. 2016))

\begin{tabular}{l|l|l|l}
\hline Grade & Vein quality & Definition of vein quality & Type of inserter needed \\
\hline 1 & Excellent & $\begin{array}{l}4-5 \text { palpable/easily visible veins suitable to cannulate } \\
\text { Clinician trained and } \\
\text { competent to insert PIVCs }\end{array}$ \\
\hline 3 & Fair & $\begin{array}{l}\text { - }-3 \text { palpable/visible veins suitable to cannulate } \\
\text { 1-2 palpable/visible veins suitable to cannulate (veins may } \\
\text { be small, scarred or difficult to find and may require heat to } \\
\text { aid vasodilation) }\end{array}$ & $\begin{array}{l}\text { Advanced/specialized } \\
\text { training }\end{array}$ \\
\hline 4 & Poor & $\begin{array}{l}\text { Veins } \text { not } \text { palpable/visible (requires visualization technology, } \\
\text { ultrasound/infrared) }\end{array}$ & $\begin{array}{l}\text { Advanced/specialized } \\
\text { training in visualization } \\
\text { technology }\end{array}$ \\
\hline 5 & $\begin{array}{l}\text { Not } \\
\text { identifiable }\end{array}$ & $\begin{array}{l}\text { No visible veins (unable to palpate or identify veins suitable } \\
\text { for cannulation) }\end{array}$ & $\begin{array}{l}\text { Advanced/specialized } \\
\text { training in visualization } \\
\text { technology }\end{array}$ \\
\hline
\end{tabular}

for the specified access device. Performing a risk assessment also determines whether the clinician can initiate the vascular access device or if the patient should be referred to a vascular access specialist to perform the procedure (Table 3.1).

\subsubsection{Peripheral Versus Central Venous Access Devices (CVAD vs PIVC)}

Determination of patient need for peripheral or central cannulation is focused primarily on the characteristics of the treatment medications and secondarily on the duration of treatment as was previously discussed and represented in Figs. 3.7 and 3.8. Other factors may also be considered for selection such as outpatient treatment requiring reliable access, patient-specific contraindications as in renal failure, history of complications and those factors previously discussed.

The use of peripherally inserted central catheters (PICCs) has grown substantially in recent years. Increasing use has led to the realization that PICCs are associated with important complications, including thrombosis and infection. Moreover, some PICCs may not be placed for clinically valid reasons. Defining appropriate indications for insertion, maintenance and care of PICCs is thus important for patient safety. An international panel was convened that applied the
RAND/UCLA Appropriateness Method to develop criteria for the use of PICCs (Chopra et al. 2015). After systematic review of the literature, scenarios related to PICC use, care and maintenance were developed according to patient population (e.g. general hospitalized, critically ill, cancer, kidney disease), indication for insertion (infusion of peripherally compatible infusates vs vesicants) and duration of use ( $\leq 5$ days, 6-14 days, 15-30 days or $\geq 31$ days). Within each scenario, appropriateness of PICC use was compared with that of other venous access devices. After a review of 665 scenarios, $253(38 \%)$ were rated as appropriate, $124(19 \%)$ as neutral/uncertain and $288(43 \%)$ as inappropriate. For peripherally compatible infusions, PICC use was rated as inappropriate when the proposed duration of use was 5 or fewer days. Midline catheters and ultrasonography-guided peripheral intravenous catheters were preferred to PICCs for use between 6 and 14 days. In critically ill patients, non-tunnelled central venous catheters were preferred over PICCs when 14 or fewer days of use were likely. In patients with cancer, PICCs were rated as appropriate for irritant or vesicant infusion, regardless of duration. The panel of experts used a validated method to develop appropriate indications for PICC use across patient populations. These criteria can be used to improve care, inform quality improvement efforts and advance the safety of medical patients. 
Prior to the selection and insertion of a vascular access device, an understanding of the indications for that device should be clear. Simple indications would include the need to administer IV fluids, whereas more specific need for parenteral nutrition would indicate a CVAD. CVADs are indicated when peripheral infusion is contraindicated due to treatment with irritating solutions and risk of phlebitis, longer dwell time is expected, frequent blood draws or there is a critical need for vasopressors, anticoagulants, insulin infusions or other dedicated infusions.

\subsubsection{Home vs Inpatient Treatment}

Patients requiring continuation of treatment from inpatient facility to home or outpatient care have considerations for the type of device inserted. The needs of the home care patient take into account reliability of the catheter, availability of trained clinicians to provide care, minimal number of lumens and consideration for the cost of maintenance. Patient preference is a necessary consideration for the type of VAD since patients may be responsible for some or all therapy administration. The patient receives informed consent and information on device options and types, risk with positive and negative components of each and specific indications for certain devices based on the need and therapy.

\subsection{Device-Specific Features}

Peripheral and central cannula and ports have specific features and indications that may make one more suitable than another when patient factors are taken into consideration (Figs. 3.6, 3.7, and 3.8). Catheter materials vary with polyurethane and silicone being predominant. Improvements in polyurethane and similar components have added increased flexibility, variations in lumen size, valved and non-valved catheters and impregnation of antibiotic or anti-

\begin{tabular}{|c|c|c|c|c|}
\hline \multirow{2}{*}{ Device Type } & \multicolumn{4}{|c|}{ Proposed Duration of Infusion } \\
\hline & $\leq 5 \mathrm{~d}$ & $6-14 d$ & $15-30 \mathrm{~d}$ & $\geq 31 \mathrm{~d}$ \\
\hline $\begin{array}{l}\text { Peripheral IV } \\
\text { catheter }\end{array}$ & $\begin{array}{l}\text { No preference between } \\
\text { peripheral IV and } \\
\text { US-guided peripheral } \\
\text { IV catheters for use } \leq 5 \mathrm{~d}\end{array}$ & & & \\
\hline $\begin{array}{l}\text { US-guided } \\
\text { peripheral IV } \\
\text { catheter }\end{array}$ & \multicolumn{2}{|c|}{$\begin{array}{l}\text { US-guided peripheral IV catheter preferred to } \\
\text { peripheral IV } \\
\text { catheter if proposed duration is } 6-14 \mathrm{~d}\end{array}$} & & \\
\hline $\begin{array}{l}\text { Nontunneled/acute } \\
\text { central venous } \\
\text { catheter }\end{array}$ & \multicolumn{2}{|c|}{$\begin{array}{l}\text { Central venous catheter preferred in critically ill } \\
\text { patients or if hemodynamic monitoring is } \\
\text { needed for } 6-14 d\end{array}$} & & \\
\hline Midline catheter & \multicolumn{2}{|c|}{$\begin{array}{c}\text { Midline catheter preferred to PICC if proposed } \\
\text { duration is } \leq 14 \mathrm{~d}\end{array}$} & & \\
\hline PICC & \multicolumn{4}{|c|}{ PICC preferred to midline catheter if proposed duration of infusion is $\geq 15 \mathrm{~d}$} \\
\hline Tunneled catheter & & & & \multirow{2}{*}{$\begin{array}{l}\text { PICC preferred to } \\
\text { tunneled catheter and } \\
\text { ports for infusion } \\
15-30 \mathrm{~d}\end{array}$} \\
\hline Port & & & & \\
\hline
\end{tabular}

Appropriate

Neutral

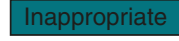

Disagreement

Fig. 3.7 Device recommendations for peripherally compatible infusions (The Michigan Appropriateness Guide for Intravenous Catheters (MAGIC) Recommendations) (Chopra et al. 2015) 


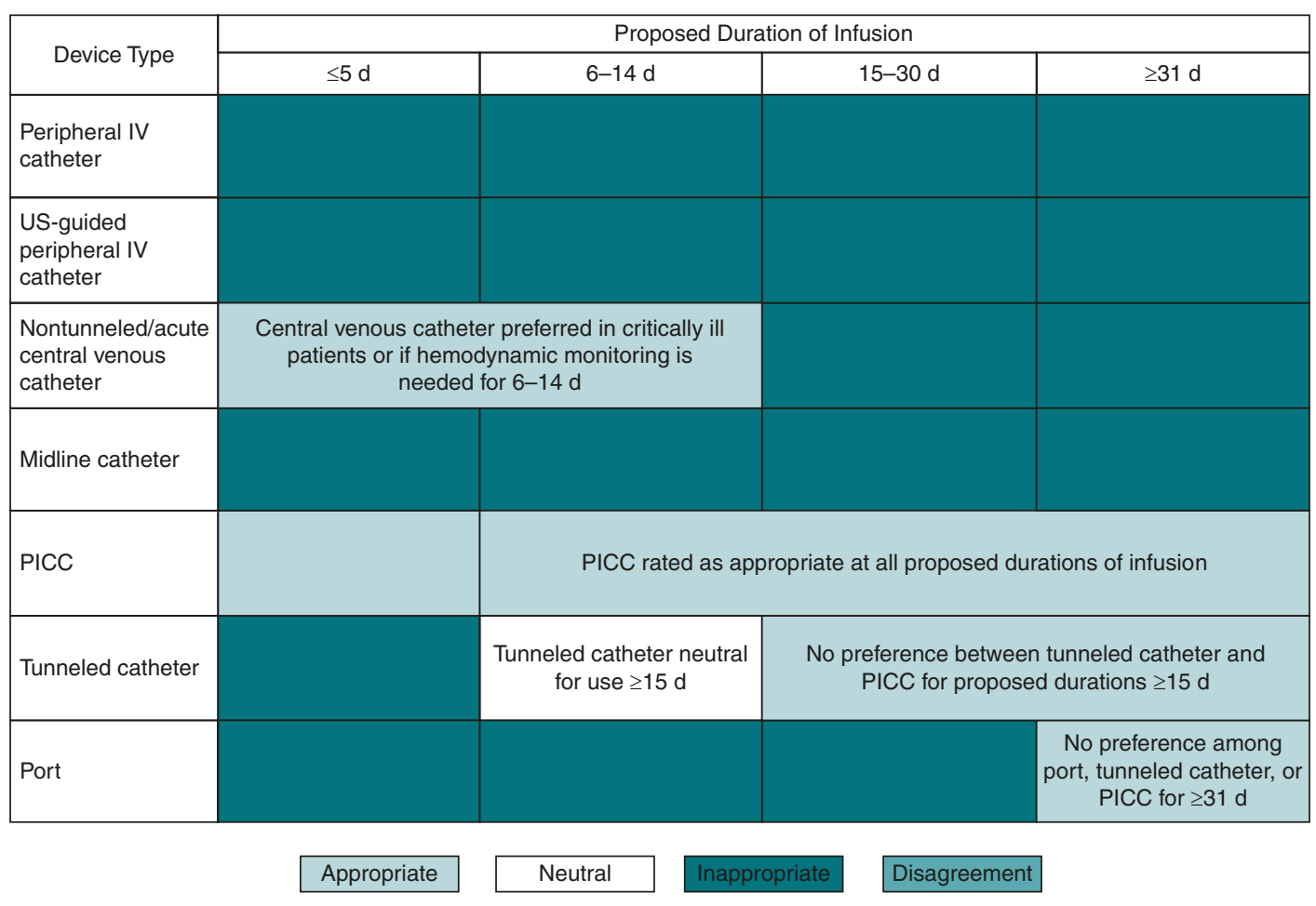

IV - intravenous: PICC - peripherally inserted central catheter; US - ultrasonography.

Fig. 3.8 Venous access device MAGIC recommendations for infusion of non-peripherally compatible infusates (Chopra et al. 2015)

septic components (Pittiruti et al. 2014). CVADs with antimicrobial properties may be the best choice for patients with compromised immunity or a propensity for infection (Kramer et al. 2017). Antithrombotic catheters may reduce risk of deep vein thrombosis (DVT) or other types of occlusions (Kleidon et al. 2018). As with any material and foreign matter placed into the body, patient sensitivities to the material may cause reactions (i.e. latex or chlorhexidine allergy). Review of evidence is necessary to measure the value of features and price of products for patient use.

Higher risk is associated with multi-lumen cannula (Chopra et al. 2014; Dobbins et al. 2003; O'brien et al. 2013; Trerotola et al. 2010). Single lumen catheters should be the default for all patients unless indications for added lumen are specified (Byrne and Penwarden 2018). Using single lumen vs multi-lumen catheters has saved millions of dollars and reduced infection and thrombosis rates (O'brien et al. 2013). When multi-lumen catheters are necessary in the case of critically ill patients, consideration should be given to use of antimicrobial catheters. In critically ill patients, it is often difficult to predict evolving need for number of lumens; therefore in acute stage of critical illness, practice is often to accept higher number of lumens and consider deescalating as the patient stabilizes. The addition of a lumen solely for blood sampling is considered inappropriate (Chopra et al. 2015). There is an overriding principle that unused lumens pose unacceptable risks of infection and should be avoided. Therefore, adopt a practice of 'least number of lumens possible'.

\subsubsection{Indications for Multi-Iumen Catheters}

- Dedicated lumen for parenteral nutrition or vasopressors

- Drug compatibilities/incompatibilities-particularly an issue in critical care patients who 
are often receiving multiple infusions of vasoactive agents

- Need for specific lumens for specific functions (i.e. haemodynamic monitoring)

- Medications with irritating characteristics, high osmolarity, vesicants and other solutions that require central administration

\subsubsection{Catheter Size}

Principles of catheter length and gauge/calibre influence flow (Nifong and Mcdevitt 2011). Poiseuille's equation and application to VAD selection are pertinent to the type of therapy needed (i.e. larger calibre/shorter length equates to increased flow rate). In critically ill patients, the need for fluid resuscitation and emergency care warrants larger calibre cannula to facilitate treatment. Effectively there needs to be a balance between the optimum flow dynamics for the catheter to fulfil its intended role, and the effect of its presence causes as a foreign body within the vessel (Piper et al. 2018).

The best solution for the 'right device' is often a multidisciplinary decision involving the vascular access specialist (VAS), the bedside nurse responsible for administering the therapy and when appropriate the patient. Rather than looking at only a single admission, the patient and VAS may identify an ongoing need for more permanent access moving to a tunnelled catheter of subcutaneously implanted port.

\subsubsection{Dialysis, Apheresis and Other Pulmonary Arterial Catheters}

Other types of catheters may be used for specific disease states or condition. Patients with chronic renal failure may require dialysis with a large bore catheter inserted through the internal jugular vein allowing high flow rates that facilitate exchange of blood. In a similar process, apheresis catheter are large bore, often tunnelled under the skin to promote stability and long-term use, promoting the process of whole blood removal for therapeutic or donor purposes. Samples of apheresis blood are processed into components such as platelets, plasma, white blood cells, red blood cells or stem cells. Another type of catheter used for pressure readings in the heart is pulmonary artery catheter. This type of catheter is positioned in the pulmonary artery (i.e. Swan-Ganz or right heart catheter) and used in the management of acute myocardial infarction and other critical conditions providing cardiac hemodynamic monitoring.

\subsection{Conclusion}

The most convenient intravenous device is not always the most efficient in facilitating the completion of the treatment plan. Intentional assessment and selection of VADs based on the patient, treatment, device and clinician provider factors combine to indicate a reliable VAD resulting in the best outcomes for the patient. The types of devices and indications for use are summarized in the Vascular Access Dashboard as shown in Fig. 3.9.

Our goal is to make the vascular access device decision-making process easier and more standardized thereby reducing variations in care, avoiding delays in treatment and increasing patient satisfaction. Developing an organized approach to vascular access device selection provides the educational, regulatory and clinical outcomes necessary for establishing and maintaining reliable access for the delivery of the treatment plan. Patient safety and preservation of vessel health is our goal. The use of the Vessel Health and Preservation program allows for the reduction of variations in care and increases positive patient outcomes. 
Vascular Access Dashboard

\begin{tabular}{|c|c|c|c|c|c|c|c|c|}
\hline Device & PIV & USGPIV & MIDLINE & PICC & $\begin{array}{l}\text { CVC } \\
\text { non-tunnelled }\end{array}$ & $\begin{array}{l}\text { Antimicrobial } \\
\text { CVC }\end{array}$ & $\begin{array}{l}\text { Tunnelled } \\
\text { CVC }\end{array}$ & PORT \\
\hline Indications & $\begin{array}{l}\text { Immediate } \\
\text { Intravenous } \\
\text { access, general } \\
\text { Infusions. } \\
\text { Treatment with } \\
\text { peripher- } \\
\text { ally compatible } \\
\text { infusion. } \\
\text { Forearm } \\
\text { placement } \\
\text { more reliable }\end{array}$ & $\begin{array}{l}\text { Difficult } \\
\text { access patient } \\
\text { (DIVA) with } \\
1 \text { or more } \\
\text { attempts } \\
\text { Treatment } 5 \\
\text { days or less } \\
\text { than } 14 \text { days } \\
\text { (transition } \\
\text { to midline). } \\
\text { Requires } \\
\text { longer } \\
\text { peripheral } \\
\text { catheter }\end{array}$ & $\begin{array}{l}\text { Difficult access } \\
\text { patient (DIVA) } \\
\text { less than } 14 \\
\text { days. More } \\
\text { reliable than } \\
\text { USGPIV and } \\
\text { may be more } \\
\text { appropriate in } \\
\text { ICU setting }\end{array}$ & $\begin{array}{l}\text { Central } \\
\text { Catheter } \\
\text { indications } \\
\text { for peripher- } \\
\text { ally incompat- } \\
\text { ible Infusions/ } \\
\text { irritants, } \\
\text { vesicants, } \\
\text { vasoactive } \\
\text { medications. } \\
\text { Measure } \\
\text { vein size to } \\
\text { approximate } \\
\text { catheter to vein } \\
\text { ratio of less } \\
\text { than } 45 \%\end{array}$ & $\begin{array}{l}\text { Central catheter } \\
\text { indications. } \\
\text { Critically ill } \\
\text { patients requiring } \\
\text { vasopressors, } \\
\text { haemodynamic } \\
\text { monitoring. } \\
\text { Subclavian } \\
\text { preferred for } \\
\text { lower infection } \\
\text { risk. }\end{array}$ & $\begin{array}{l}\text { Antimicrobial } \\
\text { catheters reduce } \\
\text { incidence of } \\
\text { infections and } \\
\text { may be most } \\
\text { appropriate for } \\
\text { ICU patients. } \\
\text { Central catheter } \\
\text { indications. } \\
\text { For high risk } \\
\text { patients or those } \\
\text { with history of } \\
\text { infections. }\end{array}$ & $\begin{array}{l}\text { Central } \\
\text { catheter } \\
\text { indications. } \\
\text { Longer term } \\
\text { treatment for } \\
\text { Parenteral } \\
\text { nutrition, } \\
\text { cancer, other }\end{array}$ & $\begin{array}{l}\text { Central } \\
\text { catheter } \\
\text { indications. } \\
\text { Longer term } \\
\text { treatment for } \\
\text { Parenteral } \\
\text { nutrition, } \\
\text { cancer, other }\end{array}$ \\
\hline Treatment & $\begin{array}{l}\text { Peripherally } \\
\text { compatible } \\
\text { infusions }\end{array}$ & $\begin{array}{l}\text { Peripherally } \\
\text { compatible } \\
\text { infusions }\end{array}$ & $\begin{array}{l}\text { Peripherally } \\
\text { compatible } \\
\text { infusions }\end{array}$ & $\begin{array}{l}\text { Peripherally } \\
\text { incompatible } \\
\text { infusions or } \\
\text { based on } \\
\text { duration }\end{array}$ & $\begin{array}{l}\text { Peripherally } \\
\text { incompatible } \\
\text { infusions } \\
\text { or based on } \\
\text { duration }\end{array}$ & $\begin{array}{l}\text { Peripherally } \\
\text { Incompatible } \\
\text { Infusions with } \\
\text { history of } \\
\text { infection }\end{array}$ & $\begin{array}{l}\text { Peripherally } \\
\text { incompatible } \\
\text { infusions and } \\
\text { based on } \\
\text { duration }\end{array}$ & $\begin{array}{l}\text { Peripherally } \\
\text { Incompatible } \\
\text { infusions and } \\
\text { based on } \\
\text { duration }\end{array}$ \\
\hline Duration & $\begin{array}{l}\text { Treatment } 5 \\
\text { days or less. } \\
\text { Clinically } \\
\text { indicated } \\
\text { removal policy } \\
\text { may extend } \\
\text { time if required } \\
\text { and without } \\
\text { complications } \\
\text { for less than } 6 \\
\text { days }\end{array}$ & $\begin{array}{l}\text { Treatment } \\
\text { less than } 6 \\
\text { days or up to } \\
14 \text { days. } \\
\text { Clinically } \\
\text { indicated } \\
\text { removal } \\
\text { policy may } \\
\text { extend time } \\
\text { if required } \\
\text { and without } \\
\text { complications }\end{array}$ & $\begin{array}{l}\text { Treatment } \\
\text { exceeding } 6 \\
\text { days and less } \\
\text { than } 14 \text { days. } \\
\text { Clinically } \\
\text { indicated } \\
\text { removal policy } \\
\text { may extend } \\
\text { time if required } \\
\text { and without } \\
\text { complications }\end{array}$ & $\begin{array}{l}\text { Treatment with } \\
\text { any infusion } \\
\text { greater or equal } \\
\text { to } 15 \text { days up to } \\
30 \text { days. } \\
\text { Difficult access } \\
\text { patient greater } \\
\text { than } 6 \text { days } \\
\text { Preference } \\
\text { for midline } \\
\text { with less than } \\
15 \text { days. Any } \\
\text { duration for } \\
\text { peripherally } \\
\text { incompatible } \\
\text { Infusions. }\end{array}$ & $\begin{array}{l}\text { Treatment 6-14 } \\
\text { days. } \\
\text { Any duration } \\
\text { for peripher- } \\
\text { ally incompat- } \\
\text { ible infusions. } \\
\text { Preferred device } \\
\text { for critically } \\
\text { ill/unstable } \\
\text { patients or if } \\
\text { haemodynamic } \\
\text { monitoring is } \\
\text { needed. }\end{array}$ & $\begin{array}{l}\text { Treatment up to } \\
30 \text { days. } \\
\text { May be } \\
\text { appropriate } \\
\text { for catheter } \\
\text { exchanges. } \\
\text { Applies to } \\
\text { PICC and chest } \\
\text { Inserted } \\
\text { CVC }(C I C C)\end{array}$ & $\begin{array}{l}\text { Treatment } \\
15-30 \text { days or } \\
\text { longer }\end{array}$ & $\begin{array}{l}\text { Treatment } \\
15-30 \text { days or } \\
\text { longer }\end{array}$ \\
\hline $\begin{array}{l}\text { Contra- } \\
\text { indications }\end{array}$ & $\begin{array}{l}\text { Circulatory } \\
\text { impairment, or } \\
\text { hemiparesis. } \\
\text { For chronic } \\
\text { renal failure } \\
\text { (CKD) patients } \\
\text { insertion } \\
\text { focused on } \\
\text { dorsum of the } \\
\text { hand. }\end{array}$ & $\begin{array}{l}\text { Circulatory } \\
\text { impairment, or } \\
\text { hemiparesis. } \\
\text { For chronic } \\
\text { renal failure } \\
\text { (CKD) patients } \\
\text { insertion } \\
\text { focused on } \\
\text { dorsum of the } \\
\text { hand. }\end{array}$ & $\begin{array}{l}\text { Circulatory } \\
\text { impairment, or } \\
\text { hemiparesis, } \\
\text { history of upper } \\
\text { extremity } \\
\text { deep vein } \\
\text { thrombosis. } \\
\text { Not appropriate } \\
\text { for CKD } \\
\text { patients }\end{array}$ & $\begin{array}{l}\text { Greater risk } \\
\text { of thrombosis } \\
\text { with unstable, } \\
\text { hypercoagu- } \\
\text { lable or patients } \\
\text { with history of } \\
\text { thrombosis. }\end{array}$ & $\begin{array}{l}\text { Coagulopathies } \\
\text { and other patient } \\
\text { specific contrain- } \\
\text { dications. }\end{array}$ & $\begin{array}{l}\text { Sensitivity to } \\
\text { chlorhexidine or } \\
\text { other impregna- } \\
\text { tlons. }\end{array}$ & $\begin{array}{l}\text { Without } \\
\text { availability of } \\
\text { trained inserter }\end{array}$ & $\begin{array}{l}\text { Morbid obesity, } \\
\text { coagulopathies }\end{array}$ \\
\hline $\begin{array}{l}\text { RISK } \\
\text { LEVEL }\end{array}$ & $\begin{array}{l}0.2-0.5 / 1000 \\
\text { catheter days }\end{array}$ & $\begin{array}{l}0.2-0.5 / 1000 \\
\text { catheter days }\end{array}$ & $\begin{array}{l}0.2-0.8 / 1000 \\
\text { catheter days }\end{array}$ & $\begin{array}{l}2.1 / 1000 \text { cath- } \\
\text { eter days } \\
\text { Higher risk in } \\
\text { Intensive Care } \\
\text { areas }\end{array}$ & $\begin{array}{l}2-5 / 1000 \text { catheter } \\
\text { days }\end{array}$ & $\begin{array}{l}1.2-1.6 / 1000 \\
\text { catheter days }\end{array}$ & $\begin{array}{l}1.6 / 1000 \text { cath- } \\
\text { eter days }\end{array}$ & $\begin{array}{l}0-0.4 / 1000 \\
\text { catheter days }\end{array}$ \\
\hline \multicolumn{3}{|c|}{$\begin{array}{l}\text { (2) } 2016 \text { PICC Excellence, Inc., nancy @ piccexcellence.C } \\
\text { References } \\
\text { 1. Ajenjo MC, Morley JC, Russo AJ, McMullen KM, Robinson C, } \\
\text { Williams RC, Warren DK (2011) Peripherally inserted central } \\
\text { venous catheter-associated bloodstream infections in hospital- } \\
\text { ized adult patients. Infect Control Hosp Epidemiol. 32(21): 125-30. } \\
\text { 2. Chopra V. Anand S. KreinSL et al., (2012) Bloodstream infec- } \\
\text { ton, venous thrombosis, and peripherally inserted central } \\
\text { catheters: reappraising the evidence. Am J Med. 125(8): 733-41. } \\
\text { 3. Maki DG. Kluger DM. Crnich CJ (2006) The risk of blood- }\end{array}$} & \multicolumn{3}{|c|}{$\begin{array}{l}\text { stream infection in adult with different intravascular devices: } \\
\text { a systematic review of } 200 \text { published prospective studies. Mayo } \\
\text { Clin Proc, } 81(9) \text { : } 1159-71 \text {. } \\
\text { 4. Pikwer A, Âkeson J. Lindgren S (2012) Complications asso- } \\
\text { ciated with peripheral or central routes for central venous } \\
\text { cannulation. Anaesthesia, 67(1): 65-71. }\end{array}$} & \multicolumn{3}{|c|}{$\begin{array}{l}\text { Wilson TJ, Stetler WR, Fletcher JJ (2013) Comparison of cath- } \\
\text { eter-related large vein thrombosis in centrally inserted versus } \\
\text { peripherally inserted central venous lines in the neurological } \\
\text { intensive care unit. Clin Neurol Neurosurg. 115(7): } 879-82 \text {. }\end{array}$} \\
\hline
\end{tabular}

Fig. 3.9 Vascular access dashboard (used with permission N. Moureau, PICC Excellence) 


\section{Case Study}

Mrs. Smith is a 76-year-old with complicated pneumonia. Her treatment process includes administration of irritating intravenous medications for at least 7 days. A short peripheral catheter was initially inserted and has infiltrated within just a few hours of insertion. Mrs. Smith has few visible veins, is a small woman and is receiving non-irritating medications.

What is the best device to consider that would facilitate completion of the treatment plan?

Following vein assessment, it was apparent that veins of the lower arm/forearm were not suitable for intravenous access. A midline catheter was selected as the best device and placed with ultrasound guidance into the basilic vein. The patient received medication infusions without interruption for 7 days completing the course of treatment. The midline catheter was removed, and the patient discharged to home.

\section{Summary of Key Points}

1. VAD selection is optimal when individualized for the patient based on treatment plan, medication types, duration and patient-specific factors.

2. Understanding the types and available options of VAD is key to selection for each patient.

3. Collaborative practice with device selection including the patient results in long-term solutions that work for all.

4. Vessel Health and Preservation process is designed to guide the clinician to select the lowest-risk device option for the patient by applying research and guidelines such as MAGIC for device appropriateness.

5. Multi-lumen devices are associated with increased complications and should only be inserted when absolutely necessary.

\section{References}

Alexander M, Hankins J. Infusion nursing: an evidencebased approach: Elsevier Health Sciences; 2009.

Babu S, Bennett J, Binks R, Fee P, Fox B, Johnston A, Klein A, Langton J, Mclure H, Tighe S. Association of Anaesthetists of Great Britain and Ireland: safe vascular access 2016. Anaesthesia. 2016;71:573-85.

Byrne D, Penwarden L. Selection of single-versus double-lumen peripherally inserted central catheters and the influence on alteplase use. J Infus Nurs. 2018;41:118-21.

Camp-Sorrell D. Access device guidelines: recommendations for nursing practice and education. 2nd ed. Oncology Nursing Society; 2011. p. 170.

Camp-Sorrell D, Matey L. Access device standards of practice for oncology nursing. Pittsburg: Oncology Nursing Society; 2017.

Castro S, Allison R. Use of midline (extended dwell peripheral IV) device improves patient safety and saves costs compared to PICCs. Poster presented at Association for Vascular Access Annual Scientific Meeting, San Antonio, TX, October 2012.

Chopra V, Ratz D, Kuhn L, Lopus T, Lee A, Krein S. Peripherally inserted central catheter-related deep vein thrombosis: contemporary patterns and predictors. J Thromb Haemost. 2014;12:847-54.

Chopra V, Flanders SA, Saint S, Woller SC, O’Grady NP, Safdar N, Trerotola SO, Saran R, Moureau N, Wiseman S, Pittiruti M, Akl EA, Lee AY, Courey A, Swaminathan L, Ledonne J, Becker C, Krein SL, Bernstein SJ, Michigan Appropriateness Guide for Intravenous Catheters Panel. The Michigan appropriateness guide for intravenous catheters (MAGIC): results from a multispecialty panel using the RAND/ UCLA appropriateness method. Ann Intern Med. 2015;163:S1-40.

Dobbins BM, Catton JA, Kite P, Mcmahon MJ, Wilcox $\mathrm{MH}$. Each lumen is a potential source of central venous catheter-related bloodstream infection. Crit Care Med. 2003;31:1688-90.

Gorski L, Hadaway L, Hagle M, Mcgoldrick M, Orr M, Doellman D. Infusion therapy: standards of practice. J Infus Nurs. 2016;39(Suppl 1):S1-S159.

Gorski, et al. 2016 (for the INS reference).

Hallam C, Weston V, Denton A, Hill S, Bodenham A, Dunn H, Jackson T. Development of the UK Vessel Health and Preservation (VHP) framework: a multi-organisational collaborative. J Infect Prev. 2016;17:65-72.

Hoggard J, Saad T, Schon D, Vesely T, Royer T. Guideline for venous access in patients with chronic kidney disease: a Position Statement from the American Society of Diagnostic and Interventional Nephrology Clinical Practice Committee and the Association for Vascular Access. Semin Dial. 2008;21:186-91.

IHI. How-to-guide: prevent central line-associated bloodstream infections. 2012.

Joint Commission. National patient safety goals: the Joint Commission Accreditation Program: Hospital. 2017. 
Kleidon T, Ullman AJ, Zhang L, Mihala G, Chaseling B, Schoutrop J, Rickard CM. How does your PICCOMPARE? A pilot randomized controlled trial comparing various PICC materials in pediatrics. J Hosp Med. 2018;13(8):517-25.

Kokotis K. Cost containment and infusion services. J Infus Nurs. 2005;28:S22-32.

Kramer RD, Rogers MA, Conte M, Mann J, Saint S, Chopra V. Are antimicrobial peripherally inserted central catheters associated with reduction in central line-associated bloodstream infection? A systematic review and meta-analysis. Am J Infect Control. 2017;45:108-14.

Maki DG, Kluger DM, Crnich CJ. The risk of bloodstream infection in adults with different intravascular devices: a systematic review of 200 published prospective studies. Mayo Clin Proc. 2006;81:1159-71.

Moureau N, Chopra V. Indications for peripheral, midline, and central catheters: summary of the Michigan appropriateness guide for intravenous catheters recommendations. J Assoc Vasc Access. 2016;21:140-8.

Nifong T, Mcdevitt T. The effect of catheter to vein ratio on blood flow rates in a simulated model of peripherally inserted central venous catheters. Chest. 2011;140:140-53.

O'brien J, Paquet F, Lindsay R, Valenti D. Insertion of PICCs with minimum number of lumens reduces complications and costs. J Am Coll Radiol. 2013;10:864-8.

O'Grady N, Alexander M, Burns L, Dellinger E, Garland J, Heard S, Lipsett P, Masur H, Mermel L, Pearson M, Raad I, Randolph A, Rupp M, Saint S. Guidelines for the prevention of intravascular catheter-related infections, 2011. Centers for Disease Control; 2011a. p. 1-83.

O'Grady N, Alexander M, Burns L, Dellinger E, Garland J, Heard S, Lipsett P, Masur H, Mermel L, Pearson M, Raad I, Randolph A, Rupp M, Saint S, Healthcare Infection Control Practices Advisory Committee (HICPAC). Centers for Disease Control Guidelines for the prevention of intravascular catheter-related infections. Clin Infect Dis. 2011b;52:e162-93.
Piper R, Carr PJ, Kelsey LJ, Bulmer AC, Keogh S, Doyle BJ. The mechanistic causes of peripheral intravenous catheter failure based on a parametric computational study. Sci Rep. 2018;8:3441.

Pittiruti M, Emoli A, Porta P, Marche B, Deangelis R, Scoppettuolo G. A prospective, randomized comparison of three different types of valved and non-valved peripherally inserted central catheters. J Vasc Access. 2014;15:519-23.

RCN. Standards for infusion therapy. 4th ed. London: Royal College of Nursing; 2005. p. 1-94.

Rickard CM, Webster J, Wallis MC, Marsh N, McGrail MR, French V, Foster L, Gallagher P, Gowardman JR, Zhang L, McClymont A. Routine versus clinically indicated replacement of peripheral intravenous catheters: a randomised controlled equivalence trial. Lancet. 2012;380(9847):1066-74.

Robinson M, Mogensen K, Grudinskas G, Kohler S, Jacobs D. Improved care and reduced costs for patients requiring peripherally inserted central catheters: the role of bedside ultrasound and a dedicated team. J Parenter Enter Nutr. 2005;29:374-9.

Scales K. Intravenous therapy: a guide to good practice. Br J Nurs. 2008;17(Suppl 8):S4-12.

Stranz M. Adjusting PH and osmolarity of infusion solutions: what is reasonable? NAVAN Annual Conference, January, 1-5. 2002.

Taheri P, Butz D, Greenfield L. Length of stay has minimal impact on the cost of hospital admission. J Am Coll Surg. 2000;191:123-30.

Trerotola S, Stavropoulos S, Mondschein J, Patel A, Fishman N, Fuchs B, Kolansky D, Kasner S, Pryor J, Chittams J. Triple-lumen peripherally inserted central catheter in patients in critical care unit: prospective evaluation. Radiology. 2010;256:312.

Wallis MC, Mcgrail MR, Webster J, Gowardman JR, Playford G, Rickard CM. Risk factors for PIV catheter failure: a multivariate analysis from a randomized control trial. Infect Control Hosp Epidemiol. 2014;35:63-8.

Open Access This chapter is licensed under the terms of the Creative Commons Attribution 4.0 International License (http://creativecommons.org/licenses/by/4.0/), which permits use, sharing, adaptation, distribution and reproduction in any medium or format, as long as you give appropriate credit to the original author(s) and the source, provide a link to the Creative Commons license and indicate if changes were made.

The images or other third party material in this chapter are included in the chapter's Creative Commons license, unless indicated otherwise in a credit line to the material. If material is not included in the chapter's Creative Commons license and your intended use is not permitted by statutory regulation or exceeds the permitted use, you will need to obtain permission directly from the copyright holder.

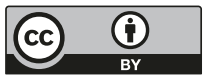

